\title{
Collagen deposition in HIV-1 infected lymphatic tissues and $T$ cell homeostasis
}

\author{
Timothy W. Schacker, ${ }^{1}$ Phuong L. Nguyen, ${ }^{2}$ Gregory J. Beilman, ${ }^{3}$ Steven Wolinsky, \\ Matthew Larson, ${ }^{1}$ Cavan Reilly, ${ }^{5}$ and Ashley T. Haase ${ }^{6}$ \\ ${ }^{1}$ Department of Medicine, \\ ${ }^{2}$ Department of Laboratory Medicine, and \\ ${ }^{3}$ Department of Surgery, University of Minnesota, Minneapolis, Minnesota, USA \\ ${ }^{4}$ Department of Medicine, Northwestern University, Chicago, Illinois, USA \\ ${ }^{5}$ Department of Biostatistics, and \\ ${ }^{6}$ Department of Microbiology, University of Minnesota, Minneapolis, Minnesota, USA
}

Lymphatic tissues (LTs) are structurally organized to promote interaction between antigens, chemokines, growth factors, and lymphocytes to generate an immunologic response and maintain normal-sized populations of $\mathrm{CD}^{+}$and $\mathrm{CD}^{+} \mathrm{T}$ cells. Inflammation and tissue remodeling that accompany local innate and adaptive immune responses to HIV-1 replication cause damage to the LT architecture. As a result, normal populations of $\mathrm{CD}^{+}$and $\mathrm{CD}^{+} \mathrm{T}$ cells cannot be supported and antigen-lymphocyte interactions are impaired. This conclusion is supported herein following LT sampling before and during anti-HIV therapy in persons with acute, chronic, and late-stage HIV-1 infection. Among seven individuals treated with anti-retroviral therapy (ART) and four individuals deferring therapy we found evidence of significant paracortical $T$ cell zone damage associated with deposition of collagen, the extent of which was inversely correlated with both the size of the $\mathrm{LT} \mathrm{CD} 4^{+} \mathrm{T}$ cell population and the change in peripheral $\mathrm{CD}^{+} \mathrm{T}$ cell count with anti-HIV therapy. The HIV-1-associated inflammatory changes and scarring in LT both limit the ability of the tissue to support and reestablish normal-sized populations of $\mathrm{CD}^{+} \mathrm{T}$ cells and suggest a novel mechanism of $T$ cell depletion that may explain the failure of ART to significantly increase $\mathrm{CD} 4^{+} \mathrm{T}$ cell populations in some HIV-1-infected persons.

This article was published online in advance of the print edition.

The date of publication is available from the JCI website, http://www.jci.org.

J. Clin. Invest. 110:1133-1139 (2002). doi:10.1172/JCI200216413.

\section{Introduction}

There is increasing recognition that the structure of secondary lymphatic tissue (LT) plays a critical role in immune system homeostasis (1-3). These architectural elements provide an organizing

Received for publication July 12, 2002, and accepted in revised form September 3, 2002.

Address correspondence to: Timothy W. Schacker, Department of Medicine/Infectious Diseases, University of Minnesota, MMC 250, 516 Delaware Street, Minneapolis, Minnesota 55455 , USA

Phone: (612) 624-9996; Fax (612) 625-4410; E-mail: schacker@lenti.med.umn.edu.

Conflict of interest: No conflict of interest has been declared.

Nonstandard abbreviations used: lymphatic tissue (LT); paracortical T cell zone (TZ); antigen-presenting cell (APC); anti-retroviral therapy (ART); highly active anti-retroviral therapy (HAART). structure that supports a unique microenvironment, or niche, necessary to support the immune functions of that tissue. The paracortical $\mathrm{T}$ cell zone (TZ), where $98 \%$ of CD4 ${ }^{+} \mathrm{T}$ cells in the human body normally reside (4), is one such niche. It is organized to mount and resolve an immune response through interaction between naive and memory $\mathrm{T}$ cells with antigen-presenting cells (APCs) and to provide a source of growth factors and cytokines. It is also a site for MHC class I, II, and selfpeptide interactions that are necessary to maintain a normal-sized population of $\mathrm{CD}^{+}$and $\mathrm{CD}^{+} \mathrm{T}$ cells (5-9).

It is within this complex $\mathrm{TZ}$ niche that most significant events of HIV-1 pathogenesis occur. Over $99 \%$ of virions produced during the course of infection are made in activated $\mathrm{CD}^{+} \mathrm{T}$ cells that reside in the $\mathrm{TZ}$, and it is here that the pathological hallmark of HIV-1 infection, depletion of $\mathrm{CD}^{+} \mathrm{T}$ cells, is manifest and where adaptive and innate immune defenses interact in an attempt to halt viral replication $(4,10-12)$. As the infection progresses, the size of the $\mathrm{TZ}$ is diminished and the organizing structure is lost (13-15). This pathological change may limit the ability of the tissue to recover normal function with antiretroviral therapy (ART).

In studies reported here, we examined the TZ niche before and during ART with the hypothesis that the extent of $\mathrm{CD}^{+} \mathrm{T}$ cell depletion at baseline and the subsequent increase in $\mathrm{CD} 4^{+} \mathrm{T}$ cell count with highly active antiretroviral therapy (HAART) is related to the extent of structural damage within the TZ. This hypothesis was suggested and supported by the importance of the $\mathrm{TZ}$ in immune system homeostasis with well-documented failures of HAART to restore the peripheral CD4 ${ }^{+} \mathrm{T}$ cell population in some individuals, despite suppression of HIV-1 replication (16, 17). In addition we found pathological changes and abnormally small TZs in LTs collected from 21 individuals with established HIV-1 infection who had no detectable plasma viremia at a mean of 20 months after initiation of HAART and had a mean increase in peripheral $\mathrm{CD}^{+} \mathrm{T}$ cell count of 151 cells $/ \mathrm{mm}^{3}$ (18). These findings show that current definitions of immune reconstitution that equate success with increases in the peripheral $\mathrm{CD}^{+} \mathrm{T}$ cell count will miss underlying structural changes in LTs that may account for the rate and extent of recovery and the variability in the peripheral $\mathrm{CD} 4^{+} \mathrm{T}$ cell response to HAART. Among the 21 patients studied, the $\mathrm{CD}^{+} \mathrm{T}$ cell count increase was 
less than 50 cells $/ \mathrm{mm}^{3}$ in six patients and the count actually decreased in four patients. In a cross-study analysis of 1,650 treatment-naive patients with a median $\mathrm{CD}^{+}$cell count of 137 cells $/ \mathrm{mm}^{3}$ (IQR, 32-310) who were enrolled in HAART treatment protocols developed by the Community Programs for Clinical Research on AIDS, $27 \%$ of 1,373 patients followed for at least 8 months had a CD $4^{+}$cell count change from baseline that was less than 50 cells $/ \mathrm{mm}^{3}$ (J. Neaton, personal communication). These data suggest there are intrinsic factors beyond suppression of viremia that may limit the ability for immunologic reconstitution, as has been suggested by others measuring proliferative responses of $\mathrm{CD}^{+}$and $\mathrm{CD}^{+} \mathrm{T}$ cells (19).

The observation that up to $25 \%$ of ART-naive persons increase peripheral $\mathrm{CD}^{+} \mathrm{T}$ cell counts by a clinically insignificant margin upon initiation of HAART supports our hypothesis that damage to the TZ structure limits restoration of the $\mathrm{CD}^{+} \mathrm{T}$ cell population. In the long struggle between immune defenses and HIV-1 that partially controls replication, the immune system is maintained in a state of chronic activation. In this condition, the associated inflammation could well damage the $\mathrm{TZ}$ so that it cannot support a normal population of T cells even though the inciting stimulus has been largely removed by HAART. To examine this possibility, we obtained LT from acute and chronically HIV-1infected, ART-naive individuals at several timepoints before and during HAART. We demonstrate for the first time to our knowledge significant architectural damage in LT from chronic inflammation and fibrosis in the $\mathrm{TZ}$ that changes the organizing structure of the tissue. The amount of fibrosis is significantly associated with the size of the population of $\mathrm{CD}^{+} \mathrm{T}$ cells in LT at the time of biopsy and the subsequent recovery of the population associated with HAART. These data provide new insight into the pathogenesis of immune depletion in HIV-1 infection and suggest that examination of LT prior to initiation of HAART may provide important information on the likelihood and extent of immune reconstitution.
These data also suggest that adjunctive anti-inflammatory therapy may improve the extent of immune recovery with HAART.

\section{Methods}

ART-naive HIV-infected individuals were recruited into a prospective study of intensive sampling of secondary LT before and during HAART. The study procedures were approved by the Human Subjects Committee of the University of Minnesota. Entry criteria were: age greater than 18, positive for HIV antibody by ELISA and Western blot, and no prior history of ART. At entry, each subject was interviewed to characterize risk factors for HIV infection, and medical records were reviewed to categorize stage and duration of infection. Clinical stage of infection was characterized as acute (proven serologically), early (within 6 months of a documented seroconversion), presymptomatic $\left(\mathrm{CD}^{+}\right.$cell count greater than 200 cells $/ \mathrm{mm}^{3}$ with positive $\mathrm{HIV}^{+}$antibody test for more than 6 months), or AIDS (CD4+ cell count less than 200 cells $/ \mathrm{mm}^{3}$ ).

All study-related procedures were carried out in the University of Minnesota General Clinical Research Center (GCRC) except for the excisional inguinal lymph node biopsy, which was completed in a research clinic at the University of Minnesota with facilities for biopsy under local anesthetic. Upon admission to the GCRC, blood was drawn for the $\mathrm{CD} 4^{+} \mathrm{T}$ cell count and plasma HIV-1 RNA. Immediately after the baseline biopsy was obtained, HAART was initiated. The choice of components for the HAART regimen was left to each individual and their primary care provider; however, it was required the subject be given a regimen meeting a minimal standard for HAART, defined as at least three drugs from two different classes. On the third day, 72 hours after initiation of HAART, and again at 1 month and 6 months after initiation of HAART, an additional excisional inguinal lymph node biopsy was completed for the patients on HAART. Patients choosing to deter HAART did not undergo a biopsy at 6 months. Peripheral blood was collected for assessment of peripheral $\mathrm{CD}^{+}$ cell count and plasma HIV-1 RNA at weekly intervals during the first month and then monthly for 6 months on all patients. In addition, LT from HIV-negative individuals was obtained from the Division of Surgical Pathology at the Fairview-University Medical Center (Minneapolis, Minnesota, USA) to act as an HIV-1-negative standard. These tissues were removed during routine surgical procedures and were reviewed by the pathologist to ensure they were histologically normal before we included them as negative control tissue.

At the time of biopsy, tissues were immediately placed into fresh 10\% buffered formalin for 4 hours and then processed through the clinical laboratories of the Fairview-University Medical Center for mounting into paraffin blocks. Five-micrometer sections were cut and stained with hematoxylin and eosin to examine overall morphology and characterize the size of the $\mathrm{TZ}$ as expanded, normal, or depleted.

Additional 5- $\mu \mathrm{m}$ sections were cut and reacted with antibodies to $\mathrm{CD} 4$ (clone 1F6; Novocastra Laboratories Ltd., Newcastle upon Tyne, United Kingdom) to quantify numbers of CD4 ${ }^{+}$ $\mathrm{T}$ cells per $\mu \mathrm{m}^{2}$ using MetaMorph software (Version 4.5; Universal Imaging Corp., Downington, Pennsylvania, USA). The methods used for quantitative image analysis of the $\mathrm{CD}^{+} \mathrm{T}$ cell population were similar to those we have used in the past $(4,10-12,20-23)$. Every fifth image (at $40 \times$ magnification) was captured and imported into the MetaMorph software program. The threshold tool was used to isolate $\mathrm{CD}^{+}$ $T$ cells and the standard area of a $\mathrm{CD}^{+}$ $T$ cell used to determine the quantity of cells per field (expressed as cells $/ \mu \mathrm{m}^{2}$ ). A total of 18 fields was analyzed for each LT sample and the mean was calculated. We have compared the mean number of $\mathrm{CD}^{+} \mathrm{T}$ cells $/ \mu \mathrm{m}^{2}$ in a tissue sample by counting cells in every field of view to the mean number of cells per unit area in 18 representative fields/tissue and found the results to be comparable (12). This procedure was completed for each LT sample at each timepoint.

To identify collagen fibers, a $5-\mu \mathrm{m}$ sample was cut from the baseline tissue and stained with a trichrome stain using the Masson method. A total of 18 images was obtained from the $\mathrm{TZ}$ of each tissue sample and imported into 
Photoshop Version 6.0 (Adobe Systems Inc., Mountain View, California, USA). The color sampler tool was used to analyze representative shades and hues of the blue-stained collagen tissue. The area of the field containing collagen was selected and the background tissue was removed from the image. The image was then transported into the MetaMorph software program to determine the percent area of tissue occupied by collagen.

\section{Results}

A total of 11 individuals were enrolled in the study, with seven initiating HAART after the first biopsy and four choosing to defer HAART. The duration of infection and clinical stage of disease are summarized in Table 1 . The protocol called for a total of four biopsies over 6 months among the patients choosing HAART, and three biopsies over 1 month for patients choosing to defer therapy. Four of the seven treated subjects (57\%) completed all four biopsies, six of seven completed three biopsies, and one subject completed only the first two biopsies. All four untreated subjects completed their three biopsies over a period of 1 month. At baseline, the median $\mathrm{CD}^{+}$ $\mathrm{T}$ cell count for all patients was 400 (range 112-905) cells $/ \mathrm{mm}^{3}$, and median plasma HIV-1 RNA was 20,014 (range 10,684-484,694) copies/ml. All HAART regimens among the seven treated subjects met the definition of HAART, with six receiving two nucleoside analogues plus at least one protease inhibitor, and the seventh receiving two nucleoside analogues plus one non-nucleoside analogue. Plasma HIV-1 RNA was reduced to less than 500 copies $/ \mathrm{ml}$ in all treated subjects by approximately 2 weeks after initiation of HAART and remained at that level for the 6-month follow-up period. The seven HAART-treated subjects had a median increase of 198 $\mathrm{CD}^{+} \mathrm{T}$ cells $/ \mathrm{mm}^{3}$ in peripheral blood over the 6-month follow-up period (range, $50-937 \mathrm{CD}^{+} \mathrm{T}$ cells $/ \mathrm{mm}^{3}$ ), but in three individuals the increase was only $\leq 62$ cells $/ \mathrm{mm}^{3}$ between baseline and the 6-month follow-up.

Histologic analysis of tissues at baseline and during follow-up. The size and character of B cell follicles and the $\mathrm{TZ}$ were assessed at each timepoint for all patients (Figure 1). At baseline in all LTs there was well-described and characteristic follicular hyperplasia except in tissue obtained from 1327, in whom follicles were hypoplastic and decreased in number, consistent with her diagnosis of AIDS (13-15). The TZ was normal in only two patients, 1329 and 1391, both of whom were in the very early stages of HIV-1 infection. In all other biopsies, the TZ was diminished, with a decreased population of cells and prominent vessels, consistent with loss of tissue volume.

As expected, there was no significant change in the histologic appearance of tissues at the 1-month follow-up for untreated subjects. Among the seven treated subjects, we observed only minimal improvement in B cell follicle hyperplasia or in the size and organization of the TZ. Of interest, among two of four subjects (1329 and 1391) with acute or early HIV infection and one patient with presymptomatic infection (1293), there was a decrease in the size and number of $B$ cell follicles with a trend toward normalcy in the size and organization of the TZ. At the 6-month biopsy we noted continued and significant improvement in these same patients. However, there was no improvement in the tissues obtained 1 month after initiation of HAART from 1324, 1086, or 1327 , or in the 6 -month sample obtained from 1327 (1324 and 1086 did not have a biopsy at 6 months).

$L T C D 4^{+} T$ cell population. We used immunohistochemistry and quantitative image analysis to quantify the $\mathrm{CD}^{+} \mathrm{T}$ cell population before initiation of and during HAART. Fivemicrometer sections were stained with anti-CD4 antibody and counted using the MetaMorph software program as previously described (4, 10-12, 20-23). Based upon previous studies we expected (and found) the number of $\mathrm{CD}^{+}$ cells to be approximately $13.9 \times 10^{-3}$ cells $/ \mu \mathrm{m}^{2}$. This is commensurate with the total body estimates of $2.2 \times 10^{11}$ $\mathrm{CD}^{+} \mathrm{T}$ cells (4) in tissue from normal, immunocompetent adults that was obtained from the Division of Surgical Pathology of Fairview-University Medical Center (Table 2). The median baseline $\mathrm{CD} 4^{+} \mathrm{T}$ cell population for these HIV-1-infected patients in our study (both treated and untreated) was

Table 1

Demographic characteristics and change in plasma HIV-1 RNA and peripheral CD4+ $T$ cell count as a response to HAART

\begin{tabular}{|c|c|c|c|c|c|c|c|c|}
\hline PT & Mo. HIV infected & Stage & $\begin{array}{c}\text { No. LT } \\
\text { biopsies }\end{array}$ & $\begin{array}{c}\text { Baseline periph. } \\
\text { CD4 } 4^{+} \\
\left(\text {cells } / \mathrm{mm}^{3}\right)\end{array}$ & $\begin{array}{c}\text { Baseline Plasma } \\
\text { HIV RNA } \\
\text { (copies/ml) }\end{array}$ & HAART regimen & $\begin{array}{l}\mathrm{CD}^{+} \text {count } \\
\text { at } 6 \mathrm{mo} \text {. } \\
\text { (cells } / \mathrm{mm}^{3} \text { ) }\end{array}$ & $\begin{array}{l}\text { Plasma HIV } \\
\text { RNA at } 6 \mathrm{mo} \\
\text { (copies } / \mathrm{ml} \text { ) }\end{array}$ \\
\hline 1329 & 1 & Acute & 4 & 370 & 484,694 & ABV, 3TC, IDV, RTV & 568 & $<50$ \\
\hline 1324 & 2 & Early & 3 & 494 & 14,696 & ABV, 3TC, IDV, RTV & 544 & $<50$ \\
\hline 1391 & 6 & Early & 4 & 290 & 24,718 & AZT, 3TC, EFV & 765 & $<50$ \\
\hline 1389 & 6 & Early & 2 & 824 & 32,173 & ABV, 3TC, IDV, RTV & 1,278 & $<50$ \\
\hline 1086 & 24 & Presx & 3 & 512 & 20,562 & AZT, 3TC, IDV & 574 & $<50$ \\
\hline 1293 & $>24$ & Presx & 4 & 905 & 14,225 & AZT, 3TC, IDV & 1,842 & $<50$ \\
\hline 1327 & $>24$ & AIDS & 4 & 112 & 12,046 & AZT, 3TC, IDV, RTV & 172 & $<50$ \\
\hline $1335^{\mathrm{A}}$ & $>24$ & Presx & 3 & 400 & 15,284 & None & ND & ND \\
\hline $1407^{A}$ & $>24$ & Presx & 3 & 372 & 31,922 & None & ND & ND \\
\hline $1406^{\mathrm{A}}$ & $>24$ & Presx & 3 & 188 & 10,684 & None & ND & ND \\
\hline $1408^{A}$ & $>24$ & Presx & 3 & 685 & 20,014 & None & ND & ND \\
\hline
\end{tabular}

APatients who have chosen to not take HAART. Periph, peripheral; pt, patient; presx, presymptomatic; nd, not done. 

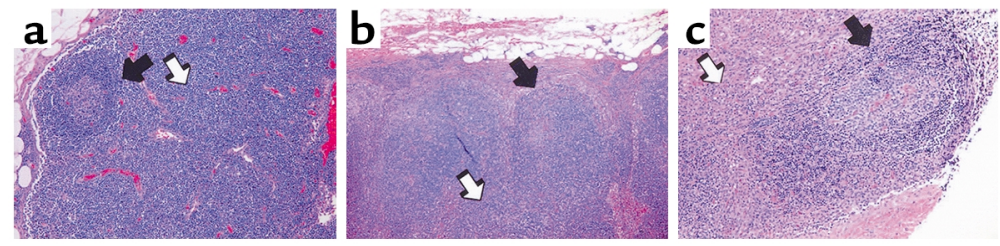

Figure 1

Histologic changes in B cell follicles and TZ characteristic of HIV-1 infection. (a) Section of lymph node from an HIV-negative patient. There is one B cell follicle that is normal in size and shape (black arrow). The TZ is normal in size with a normal population of cells (white arrow). (b) Section of a lymph node from an HIV-1-infected patient with presymptomatic HIV-1 infection. The follicles are hyperplastic and disorganized (black arrow), and the TZ is small and somewhat depleted of cells (white arrow). (c) Lymph node section from a patient with AIDS. The follicular space is disorganized and without structure (black arrow), and the TZ is unrecognizable with few cells (white arrow). All images are at a magnification of $\times 4$.
$6.81 \times 10^{-4} \mathrm{cells} / \mu \mathrm{m}^{2}$ (range, $2.41 \times 10^{-4}$ to $9.78 \times 10^{-4}$, which is approximately $50 \%$ of normal (Table 2 ). While there was general correlation between stage of disease and the size of the $\mathrm{LT} \mathrm{CD} 4^{+} \mathrm{T}$ cell population (the earlier the stage of infection the higher the LT CD4 ${ }^{+}$T cell count), it was not significant. We found no correlation between the baseline LT $\mathrm{CD}^{+} \mathrm{T}$ cell count and the baseline peripheral CD4 ${ }^{+} \mathrm{T}$ cell count or plasma HIV-1 RNA ( $P=0.5$, Wilcoxin signed rank test, Figure 2). This suggests that among HIV-1-infected persons who are not taking ART, common measures of disease severity (duration or stage of infection, peripheral $\mathrm{CD} 4^{+} \mathrm{T}$ cell count, and plasma HIV-1 RNA) do not correlate with the size of the baseline LT $\mathrm{CD} 4^{+} \mathrm{T}$ cell population.

We observed a general trend toward expansion of the $\mathrm{LT} \mathrm{CD} 4^{+} \mathrm{T}$ cell population with HAART in all treated patients, and a significant increase in the $\mathrm{LT} \mathrm{CD}^{+} \mathrm{T}$ cell population among the four treated individuals who provided LT at 6 months (twosample paired Student $t$ test, $P=0.0039)$ (Table 2). At baseline, the mean population size for all patients was $6.81 \times 10^{-4} \mathrm{cells} / \mu \mathrm{m}^{2}$ and among the treated patience, at 1 month it was $7.51 \times 10^{-4} \mathrm{cells} / \mu \mathrm{m}^{2}$ (range $2.75 \times 10^{-4}$ to $10.30 \times 10^{-4}$ ) cells $/ \mu^{2}$ $(n=6)$, representing only a $2 \%$ increase over baseline to $54 \%$ of the normal population size. After 6 months of HAART, the median $\mathrm{CD} 4^{+}$ $\mathrm{T}$ cell population size was $11.1 \times 10^{-4}$ cells $/ \mu^{2}(n=4)$, representing a mean $29 \%$ increase in the overall size of the LT population, with some patients
(1329, 1293, and 1391) having a near-normal $\mathrm{CD}^{+} \mathrm{T}$ cell population and others (1327) remaining significantly diminished.

Measurement of percent area collagen as a marker of fibrotic changes in LT. We consistently found prominent foci of scar tissue in LTs, suggesting that inflammation-associated damage might be reducing the capacity of the $\mathrm{TZ}$ niche to maintain cellular homeostasis. We hypothesized that the damage might correlate with the size of the $\mathrm{CD}^{+} \mathrm{T}$ cell population, and tested this hypothesis by measuring the percentage of the $\mathrm{TZ}$ area occupied by collagen.

We used a trichrome stain to identify collagen deposition in the $\mathrm{TZ}$ and observed significantly greater deposition among all samples from HIV-1infected subjects than was found in the HIV-1-negative sample (Figure 3). In the tissue obtained from the HIV-1-negative patient ( $\mathrm{Nl}$ in Table 3 ), less than $1 \%$ of the $\mathrm{TZ}$ area consisted of collagen; however, among tissues from all HIV-1-infected persons, the values ranged from $2.2 \%$ to $19.9 \%$ (median 10.0\%). To determine whether there was an association between the amount of fibrosis in the $\mathrm{TZ}$ and the size of the $\mathrm{CD}^{+} \mathrm{T}$ cell population in the $\mathrm{TZ}$, we compared the percent area collagen in the TZ with the size of the $\mathrm{CD} 4^{+} \mathrm{T}$ cell population in the baseline LT biopsy specimen. We found a significant inverse relationship (Figure 4a). The greater the area occupied by collagen, the fewer $\mathrm{CD}^{+} \mathrm{T}$ cells were found in the LT $\left(R^{2}=0.72, P<0.0001\right.$, Spearman rank correlation). There was no association between percent area collagen and duration or stage of HIV-1

\section{Table 2}

Quantitative comparison of CD4+ T cells in LT and peripheral blood

\begin{tabular}{|c|c|c|c|c|c|c|c|c|}
\hline \multirow[b]{2}{*}{ PT } & \multicolumn{3}{|c|}{$\mathrm{LT} \mathrm{CD}^{+}{ }^{+}$cells ${ }^{\mathrm{A}}$} & \multicolumn{5}{|c|}{ Peripheral $\mathrm{CD}^{+}$cells } \\
\hline & Baseline & Day 3 & Mo. 1 & Mo. 6 & Baseline & Day 3 & Mo. 1 & Mo. 6 \\
\hline \multicolumn{9}{|c|}{ HIV negative patient } \\
\hline $\mathrm{N} I^{\mathrm{B}}$ & 13.9 & - & - & - & - & - & - & - \\
\hline \multicolumn{9}{|c|}{$\begin{array}{l}\text { Treated } \mathrm{HIV}^{+} \text {patients } \\
\text { Acute or early }\end{array}$} \\
\hline 1329 & 9.78 & 7.10 & 9.96 & $13.0^{\mathrm{B}}$ & 370 & 439 & 819 & 871 \\
\hline 1324 & 6.14 & 5.84 & 7.27 & - & 494 & 339 & 466 & 544 \\
\hline 1391 & 8.71 & 8.59 & 10.30 & $11.0^{\mathrm{B}}$ & 234 & 414 & 436 & 765 \\
\hline 1389 & 8.95 & - & - & - & 824 & 994 & 828 & 1278 \\
\hline \multicolumn{9}{|c|}{ Presymptomatic } \\
\hline 1086 & 4.45 & 5.72 & 7.81 & - & 512 & 450 & 236 & 574 \\
\hline 1293 & 8.08 & - & 7.00 & $11.2^{\mathrm{B}}$ & 905 & 915 & 1,098 & 1842 \\
\hline \multicolumn{9}{|c|}{ AIDS } \\
\hline 1327 & 2.41 & - & 2.75 & $6.63^{\mathrm{B}}$ & 112 & 109 & 172 & 180 \\
\hline \multicolumn{9}{|c|}{$\begin{array}{l}\text { Untreated } \mathrm{HIV}^{+} \text {patients } \\
\text { Presymptomatic }\end{array}$} \\
\hline 1335 & 7.44 & - & 7.77 & - & 400 & 468 & 359 & ND \\
\hline 1407 & 8.5 & Pend. & 8.27 & - & 372 & 483 & 572 & Pend. \\
\hline 1406 & 4.53 & Pend. & 4.14 & - & 188 & 173 & 181 & Pend. \\
\hline 1408 & 5.88 & 8.22 & 6.58 & - & 685 & 744 & 681 & Pend. \\
\hline
\end{tabular}

AThe $\mathrm{CD} 4^{+} \mathrm{T}$ cell population in LT is expressed as no. cells $\times 10^{-4} / \mu \mathrm{m}^{2}$. BThe difference between baseline and 6-month LT CD4 ${ }^{+}$T cell counts is significant (two-tailed Student $t$ test, $P=0.0039$ ). N1, HIV-negative control. Pend, pending. 


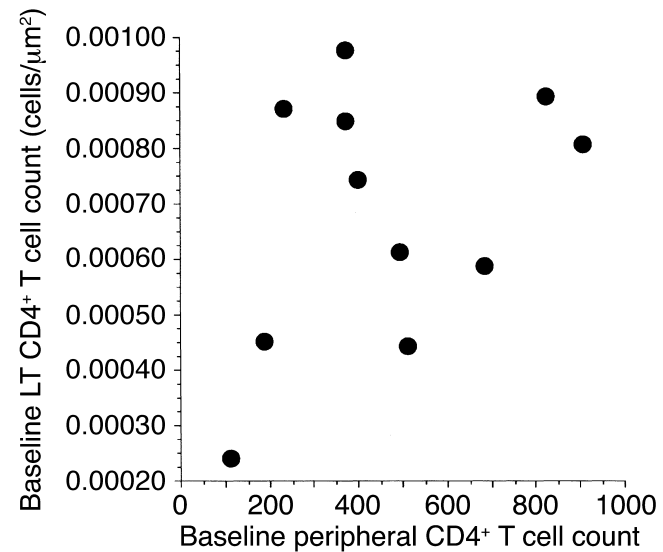

Figure 2

Comparison of peripheral versus $\mathrm{LTCD} 4^{+} \mathrm{T}$ cell population at baseline shows no significant relationship.

infection, baseline peripheral $\mathrm{CD} 4^{+} \mathrm{T}$ cell count, or plasma HIV-1 RNA, which are the markers of disease severity that are often used in the clinic.

To determine the impact of $\mathrm{TZ}$ fibrosis on the response to HAART and immune reconstitution, we compared the percent area collagen with the change in peripheral $\mathrm{CD} 4^{+} \mathrm{T}$ cell count over the 6-month follow-up period. We used the peripheral count for two reasons: this is the most common marker of HAART efficacy used in clinical practice, and we did not have a 6-month lymph node biopsy from all of the HAART-treated patients. Using multiple regression, we found a significant relationship between the change in the peripheral $\mathrm{CD}^{+} \mathrm{T}$ cell count over 6 months and the baseline percent area collagen, controlling for baseline peripheral $\mathrm{CD}^{+} \mathrm{T}$ cell count and baseline viral load $\left(R^{2}=0.91, P<0.001\right)$ (Figure $\left.4 \mathrm{~b}\right)$. This suggests that a single baseline measurement of percent area of LT occupied by collagen before initiation of HAART has predictive power to estimate the change in peripheral $\mathrm{CD}^{+} \mathrm{T}$ cell count, independent of baseline peripheral $\mathrm{CD} 4^{+} \mathrm{T}$ cell count or plasma HIV-1 RNA.

\section{Discussion}

We have prospectively examined the impact of chronic HIV-1 infection on the structure and function of the TZ niche to gain further insight into mechanisms of immune reconstitution and factors that might inhibit or enhance this process. At baseline we observed significant depletion of the $\mathrm{LT} \mathrm{CD} 4^{+} \mathrm{T}$ cell population in every patient and at all stages of HIV-1 infection. Others have made the observation that LT obtained from HIV-1infected persons can contain a variable amount of collagen $(24,25)$. We show

\section{Figure 3} area in black was calculated. that the amount of collagen in the TZ is significantly associated with the number of $\mathrm{CD}^{+} \mathrm{T}$ cells occupying that same space and the magnitude of $\mathrm{CD} 4^{+} \mathrm{T}$ cell recovery with HAART. We view this measure of collagen as a marker of damage to the structure and function of LT before therapy is begun and as a potential predictor of the change in $\mathrm{CD}^{+} \mathrm{T}$ cell count with HAART.

These relationships between collagen deposition in the $\mathrm{TZ}$ and the $\mathrm{CD} 4^{+}$ $\mathrm{T}$ cell population before and during HAART suggest that in the state of chronic immune activation and inflammation from ongoing HIV-1 replication, there is damage and disruption to the $\mathrm{LT}$ microenvironment that results in the impaired recruitment, retention, and proliferation of $\mathrm{CD}^{+} \mathrm{T}$ cells. We would anticipate that the greatest impact would be on the subset with the naive phenotype. This is suggested by investigations in the mouse immune system showing that normal-sized populations of naive
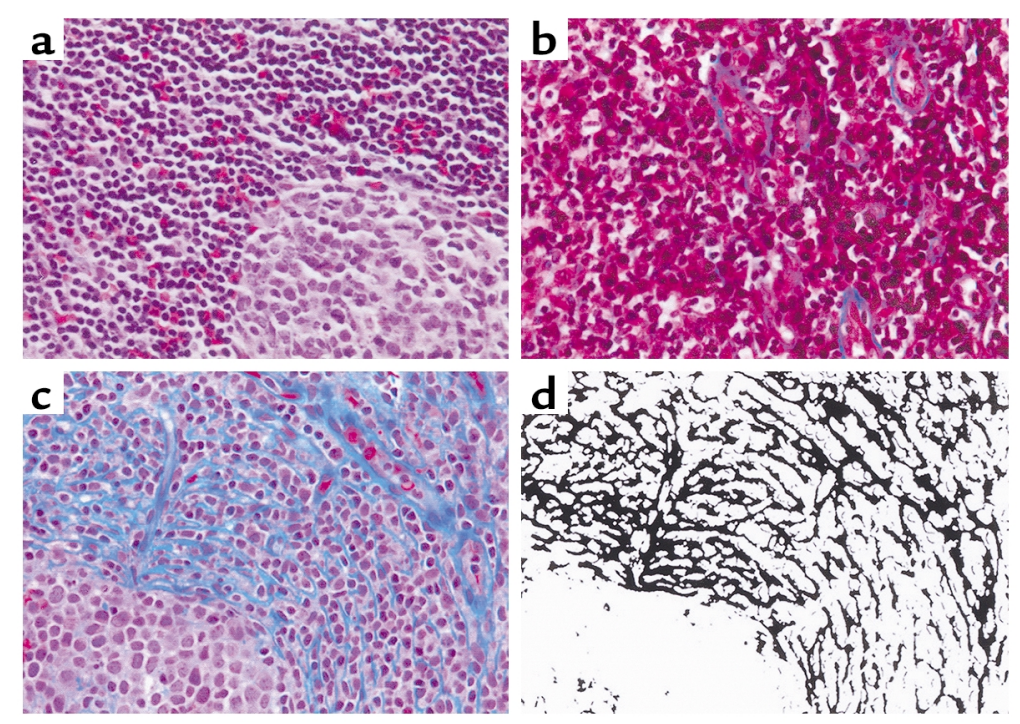

Quantitative analysis of collagen deposition in the TZ in HIV-1-infected persons. Tissues were stained with a modified trichrome stain using the Masson method to identify collagen fibers as blue. (a) HIV-negative patient. Collagen makes up $0.23 \%$ of the tissue section. (b) Patient 1407. Section shows collagen deposition (stained blue) in the wall of the high endothelial venule. Percent area collagen was calculated to be $2.2 \%$. (c) Patient 1327, the patient with AIDS. In contrast to $\mathbf{b}$, this section shows significant deposition of collagen in the TZ. Percent area collagen was calculated to be $18.6 \%$. A total of 18 images from each tissue sample, imported through the Photoshop program (Adobe, Version 6.0), are displayed (magnification, $\times 40$ ). (d) The transformed Photoshop image from $\mathbf{c}$. All shades of blue representing collagen in $\mathbf{c}$ were averaged and displayed in black; non-collagen area was removed. This image was imported into the MetaMorph imaging program and the percent 
Table 3

Percent area collagen and change in peripheral CD4+ cell count and plasma HIV-1 RNA over 6 months of follow-up

\begin{tabular}{|c|c|c|c|c|c|c|c|}
\hline PT & Mo. $\mathrm{HIV}^{+}$ & Stage & $\begin{array}{c}\text { Baseline peripheral } \\
\mathrm{CD}^{+} \text {cells } \\
\left(\text { cells } / \mathrm{mm}^{3}\right)\end{array}$ & $\begin{array}{c}\mathrm{CD}^{+} \text {at } \\
6 \mathrm{mo} . \\
\text { (cells } / \mathrm{mm}^{3} \text { ) }\end{array}$ & $\begin{array}{c}\text { Baseline plasma } \\
\text { HIV RNA } \\
\text { (copies/ml) }\end{array}$ & $\begin{array}{l}\text { Plasma HIV } \\
\text { RNA at } 6 \text { mo. } \\
\text { (copies } / \mathrm{ml} \text { ) }\end{array}$ & Percent area collagen \\
\hline $\mathrm{NI}$ & - & - & - & - & - & - & 0.23 \\
\hline 1329 & 1 & Acute & 370 & 568 & 484,694 & $<50$ & 5.4 \\
\hline 1324 & 2 & Early & 494 & 544 & 14,696 & $<50$ & 11.2 \\
\hline 1391 & 6 & Early & 290 & 765 & 24,718 & $<50$ & 2.7 \\
\hline 1389 & 6 & Early & 824 & 1278 & 32,173 & $<50$ & 6.2 \\
\hline 1086 & 24 & Presx & 512 & 574 & 20,562 & $<50$ & 12.3 \\
\hline $1335^{\mathrm{A}}$ & $>24$ & Presx & 400 & - & 15,284 & ND & 13.3 \\
\hline 1407 & $>24$ & Presx & 372 & - & 31,922 & Pend. & 2.2 \\
\hline $1406^{A}$ & $>24$ & Presx & 188 & - & 10,684 & Pend. & 19.9 \\
\hline $1408^{A}$ & $>24$ & Presx & 685 & - & 20,014 & Pend. & 10.0 \\
\hline 1293 & $>24$ & Presx & 905 & 1842 & 14,225 & $<50$ & 2.4 \\
\hline 1327 & $>24$ & AIDS & 112 & 172 & 12,046 & $<50$ & 18.6 \\
\hline
\end{tabular}

Patients are not receiving therapy. ${ }^{\mathrm{A}}$

$\mathrm{CD}^{+} \mathrm{T}$ cells are dependent on intact LT structure (7) and our demonstration that the pool of naive $\mathrm{CD} 4^{+} \mathrm{T}$ cells in LT obtained from HIV-1-infected humans in the presymptomatic stage of disease is significantly depleted (4). Collectively, these data suggest a novel mechanism of $\mathrm{CD}^{+} \mathrm{T}$ cell depletion in HIV-1 infection, with viral replication in the TZ leading to inflammation and localized tissue damage such that the growth factors and overall structure are unable to support the normal resident population of cells. This is the most likely mechanism to explain collagen deposition in the TZ; however, it is possible that another mechanism would explain this phenomenon. Whatever the mechanism, in effect, the space that is optimally organized to maintain $98 \%$ of the $\mathrm{CD}^{+} \mathrm{T}$ cell population is slowly destroyed through fibrosis and tissue remodeling.

This process of fibrosis leading to loss of tissue function is analogous to the pathogenesis of cirrhosis in chronic active hepatitis $\mathrm{B}$ and $\mathrm{C}$ infection, wherein ongoing viral replication in hepatocytes leads to a state of chronic inflammation and fibrosis. Over time, functional liver tissue is replaced by collagen, and the patient develops cirrhosis with all of its sequelae. In HIV-1 infection, secondary LTs become gradually replaced by collagen, leading to a gradual inability to maintain a population of $\mathrm{CD}^{+} \mathrm{T}$ cells. Recognition of this process suggests new opportunities for anti-HIV-1 therapy. Presently, most therapeutic strategies focus on suppression of viral replication. However, it may be that adjunctive anti-inflammatory therapy would provide substantial benefit by limiting, and possibly reversing, the damage to the TZ. Furthermore, longitudinal studies that assess changes in the structure of the $\mathrm{TZ}$ after prolonged HIV-1 therapy would be required
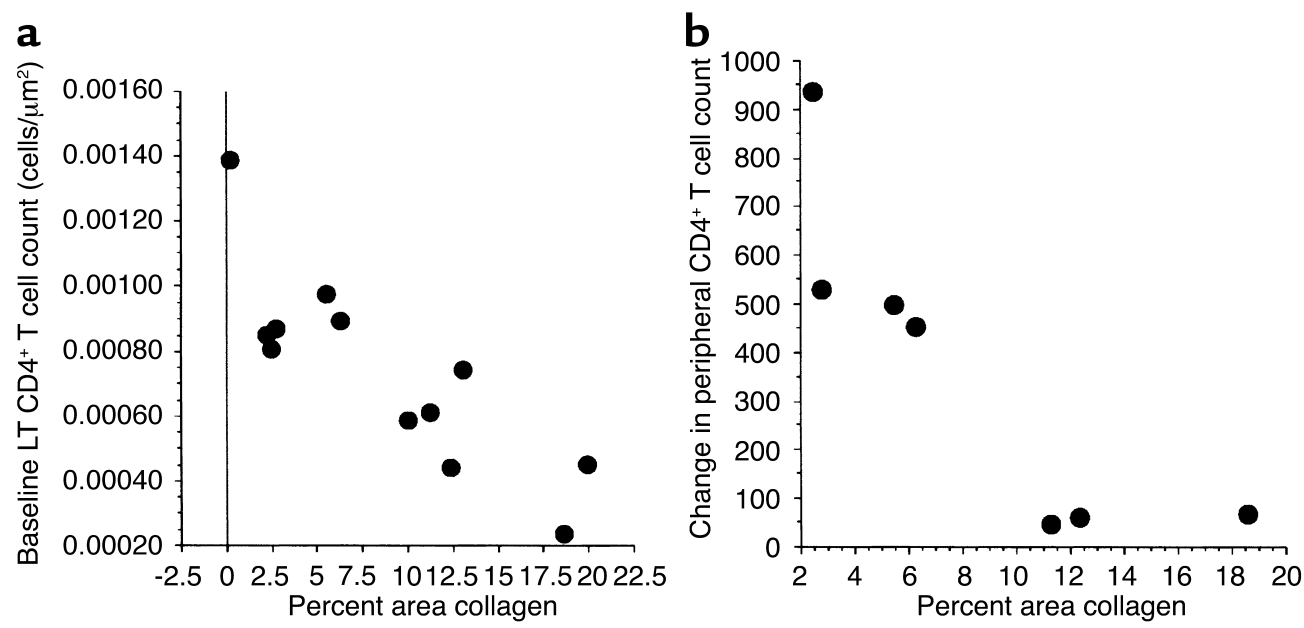

\section{Figure 4}

Relationship between the percentage of LT occupied by collagen and two parameters: baseline LT CD4+ $T$ cell population and change in peripheral CD4 ${ }^{+} T$ cell count after 6 months. (a) Size of the baseline LT CD4 ${ }^{+} T$ cell population is compared with the percent area of the TZ occupied by collagen. There is a significant correlation between these values $\left(R^{2}=0.72, P<0.0001\right.$, Spearman rank correlation). (b) Change in the peripheral $C D 4^{+} T$ cell population after 6 months of HAART is compared with the percent area of the TZ occupied by collagen. There is significant correlation between these measurements $\left(R^{2}=0.91, P<0.001\right)$. 
to determine whether the niche damage is reversible and what role anti-inflammatory therapy would have.

In summary, our data provide new insights into HIV-1 pathogenesis and offer a potential explanation for the failure of HAART to provide complete immune reconstitution in some individuals. The finding that a single measurement of collagen in LT before initiation of HAART is predictive of subsequent reestablishment of the $\mathrm{CD}^{+} \mathrm{T}$ cell population suggests that a staging lymph node biopsy would provide useful information on when to initiate therapy. Recognition of the role of inflammation in the pathogenesis of $\mathrm{CD}^{+} \mathrm{T}$ cell depletion suggests that studies of the impact of antiinflammatory drugs on immune reconstitution are warranted.

\section{Acknowledgments}

The authors would like to thank Sally McCasland, Mindie Orey, and Andy Wallschlaeger in the Division of Surgical Pathology, and Ann Maruska, Debbie Spade, and Karen Scherping in the Immunohistology Laboratory of the Fairview-University Medical Center for their help with preparation and staining of the lymphatic tissues, Gerry Sedgewick for his assistance with the MetaMorph software, Yolanda Sargent-Brown for her assistance with lymph node biopsy, Carrie Tessmar for her assistance with Institutional Review Board and patient scheduling, and Tim Leonard for his assistance in the preparation of the figures. This work was supported by NIH grants P130 CA-79458-01, 1RO1 DE-1293401, MO1 RR-00400, 2UO1 AI-041535, and R37 AI-28246.
1. Kaldjian, E.P., Gretz, J.E., Anderson, A.O., Shi, Y., and Shaw, S. 2001. Spatial and molecular organ ization of lymph node $\mathrm{T}$ cell cortex: a labyrinthine cavity bounded by an epitheliumlike monolayer of fibroblastic reticular cells anchored to basement membrane-like extracellular matrix. Int. Immunol. 13:1243-1253.

2. Gretz, J.E., Kaldjian, E.P., Anderson, A.O., and Shaw, S. 1996. Sophisticated strategies for information encounter in the lymph node: the reticular network as a conduit of soluble information and a highway for cell traffic. J. Immunol. 157:495-499.

3. Gretz, J.E., Norbury, C.C., Anderson, A.O. Proudfoot, A.E., and Shaw, S. 2000. Lymphborne chemokines and other low molecular weight molecules reach high endothelial venules via specialized conduits while a functional barrier limits access to the lymphocyte microenvironments in lymph node cortex. J. Exp. Med 192:1425-1440.

4. Zhang, Z.Q., et al. 1998. Kinetics of $\mathrm{CD}^{+} \mathrm{T}$ cell repopulation of lymphoid tissues after treatment of HIV-1 infection. Proc. Natl. Acad. Sci. USA. 95:1154-1159.

5. Campbell, D.J., and Butcher, E.C. 2002. Rapid acquisition of tissue-specific homing phenotypes by $\mathrm{CD} 4\left(^{+}\right) \mathrm{T}$ cells activated in cutaneous or mucosal lymphoid tissues. J. Exp. Med. 195:135-141.

6. Dai, Z., and Lakkis, F.G. 2001. Cutting edge: secondary lymphoid organs are essential for maintaining the CD4, but not CD8, naive T cell pool. J. Immunol. 167:6711-6715.

7. Dummer, W., Ernst, B., LeRoy, E., Lee, D., and Surh, C. 2001. Autologous regulation of naive T cell homeostasis within the $\mathrm{T}$ cell compartment. J. Immunol. 166:2460-2468.

8. Rathmell, J.C., Farkash, E.A., Gao, W., and Thompson, C.B. 2001. IL-7 enhances the survival and maintains the size of naive $\mathrm{T}$ cells. J. Immunol. 167:6869-6876.

9. Ploix, C., Lo, D., and Carson, M.J. 2001. A ligand for the chemokine receptor CCR7 can influence the homeostatic proliferation of CD4 T cells and progression of autoimmunity. J. Immunol. 167:6724-6730

10. Haase, A.T., et al. 1996. Quantitative image analysis of HIV-1 infection in lymphoid tissue. Science. 274:985-989.

11. Haase, A.T. 1999. Population biology of HIV-1 infection: viral and $\mathrm{CD} 4^{+} \mathrm{T}$ cell demographics and dynamics in lymphatic tissues. Annu. Rev. Immunol. 17:625-656.

12. Schacker, T., et al. 2001. Productive infection of $\mathrm{T}$ cells in lymphoid tissues during primary and early human immunodeficiency virus infection. J. Infect. Dis. 183:555-562.

13. Pantaleo, G., Graziosi, C., and Fauci, A.S. 1993. The role of lymphoid organs in the immunopathogenesis of HIV infection. AIDS. 7:S19-S23.
14. O'Murchadha, M.T., Wolf, B.C., and Neiman, R.S. 1987. The histologic features of hyper plastic lymphadenopathy in AIDS-related complex are nonspecific. Am. J. Surg. Pathol. 11:94-99.

15. Biberfeld, P., Porwit-Ksiazek, A., Bottiger, B., Morfeldt-Mansson, L., and Biberfeld, G. 1985. Immunohistopathology of lymph nodes in HTLV-III infected homosexuals with persistent adenopathy or AIDS. Cancer Res. 45:4665s-4670s.

16. Martin, J.C., Soriano, V., Jimenez-Nacher, I., Martinez, P., and Gonzalez-Lahoz, J. 2001. Overall trends in CD4 counts and plasma viremia in an urban clinic since the introduction of highly active antiretroviral therapies. Clin. Microbiol. Infect. 7:678-681.

17. Martin, M., Echevarria, S., Leyva-Cobian, F. Pereda, I., and Lopez-Hoyos, M. 2001. Limited immune reconstitution at intermediate stages of HIV-1 infection during one year of highly active antiretroviral therapy in antiretroviralnaive versus non-naive adults. Eur. J. Clin. Microbiol. Infect. Dis. 20:871-879.

18. Schacker, T.W., et al. 2002. Persistent abnormalities in lymphoid tissues of HIV-infected persons successfully treated with anti-retroviral therapy. J. Infect. Dis. 108:1092-1097.

19. Sieg, S.F., Mitchem, J.B., Bazdar, D.A., and Lederman, M.M. 2002. Close link between $\mathrm{CD}^{+}$and $\mathrm{CD}^{+} \mathrm{T}$ cell proliferation defects in patients with human immunodeficiency virus disease and relationship to extended periods of $\mathrm{CD}^{+}$lymphopenia. J. Infect. Dis. 185:1401-1416.

20. Li, Q., Gebhard, K., Schacker, T., Henry, K., and Haase, A.T. 1997. The relationship between tumor necrosis factor and human immunodeficiency virus gene expression in lymphoid tissue. J. Virol. 71:7080-7082.

21. Schacker, T., et al. 2000. Rapid accumulation of human immunodeficiency virus (HIV) in lymphatic tissue reservoirs during acute and early HIV infection: implications for timing of anti retroviral therapy. J. Infect. Dis. 181:354-357

22. Zhang, Z.Q., et al. 1999. Reversibility of the pathological changes in the follicular dendritic cell network with treatment of HIV-1 infection. Proc. Natl. Acad. Sci. USA. 96:5169-5172.

23. Cavert, W., et al. 1997. Kinetics of response in lymphoid tissues to antiretroviral therapy of HIV-1 infection. Science. 276:960-964.

24. Schinella, R.A., Muller, W.D., and Greco, M.A. 1990. The lymph node in AIDS: a light microscopic and ultrastructural study. Prog. AIDS Pathol. 2:13-23.

25. Baroni, C.D., and Uccini, S. 1990. Lymph nodes in HIV-positive drug abusers with persistent generalized lymphadenopathy: histology, immunohistochemistry, and pathogenic correlations. Prog. AIDS Pathol. 2:33-50. 